Marie Garrett

\title{
Newfound Press
}

\section{Participating in the future of scholarly publishing}

A

Tennessee country woman's memoirs, a

German picaresque novel, an economics journal and a music journal, observations about democracy in America, reflections on Cormac McCarthy's writings-these works comprise the first publications of Newfound Press,${ }^{1}$ the digital imprint of the University of Tennessee (UT) Libraries. This demonstration project affords the libraries the opportunity to explore the impact of new technologies on scholarly communication and provides a means for helping faculty bring their scholarship to the attention of the academy.

Newfound Press makes scholarly, theoretical, and practical information widely accessible and freely available. In particular, the imprint distributes specialized materials that may not reach publication in a market-driven economy. The work of the press acknowledges the changing patterns of scholarly communication. A recent OCLC report notes that the "technological movement is changing the way faculty and students access, create and use information resources" and that researchers "increasingly rely on the availability of information on the scholar's desktop." ${ }^{2}$

David Lewis sees a significant new role for libraries in developing "the ability to assist and support faculty in the creation and collection of . . . content." 3 The potential to create new forms of scholarship and to foster more robust involvement with scholarly publishing supports the 21st-century mission of libraries. Collection development in the digital age involves moving beyond traditional acquisition of resources to helping faculty and other researchers create new knowledge. This new role complements the library's advocacy for open access and its efforts to raise awareness of scholarly communication issues on campus. Linda Phillips, who leads in the development of Newfound Press, states, "University libraries are catalysts for the academic community to create new knowledge." 4

The inspiration for establishing a digital press came from projects such as Virginia Tech's hosting of electronic journals ${ }^{5}$ and the University of Wisconsin's establishment of Parallel Press. ${ }^{6}$ The work of higher education visionaries, including David E. Shulenburger, ${ }^{7}$ Clifford Lynch, ${ }^{8}$ and Jean Claude Guédon, ${ }^{9}$ provided encouragement and direction. High costs of scholarly journals and the pricing practices of some commercial publishers added urgency. UT's Newfound Press demonstration supports recent evidence that "faculty have a strong desire for greater support in creating, validating and publishing their digital research output."

\section{The Editorial Board}

In 2004, the faculty advisory board, representing a variety of disciplines and a wide array of experience, gathered to determine possible directions for Newfound Press. The group sponsored a survey of the UT faculty to learn about their use and creation of digital multimedia. The survey gathered information about faculty scholarly activities and marketed the press on campus. In 2006, the advisory group, with a few additional mem-

Contact Joyce L. Ogburn-series editor, cochair of the ACRL Scholarly Communications Committee, and university librarian at the University of Utahwith articles ideas, e-mail: joyce.ogburn@utah.edu

Marie Garrett is English and theatre librarian at the University ofTennessee Libraries, e-mail:mgarrett@utk. edu

(0) 2008 Marie Garrett 
bers, including the UT Press director, became the Editorial Board for Newfound Press.

Seven criteria developed by the Editorial Board define priorities for soliciting and evaluating potential publications. The press seeks content that 1) has a narrow focus with limited market potential in traditional venues, 2) reflects scholarly rigor and a creative approach to the content, 3) demonstrates innovative presentation, 4) reflects regional relevance, 5) merits wide dissemination and preservation, 6) reflects interest across disciplines, and 7) promotes research and educational activities at UT. Mark Sandler urges libraries to "facilitate communication in all its forms." ${ }^{11}$

\section{Values}

Newfound Press decided to experiment with both traditional and emerging formats for scholarly communication. The current demonstration includes four categories: books, journals, multimedia, and conference proceedings. The first publications in these areas reflect some of the project's key values and demonstrate advantages of publishing in the digital environment.

- Newfound Press values material too specialized for a commercial market and makes that content available any time, anywhere. The digital format adds value for searching texts. Goodness Gracious, Miss Agnes: Patchwork of Country Living and Travels of a Country Woman, by Lera Knox, chronicle life in Depression-era Tennessee and collect Knox's newspaper columns describing such events as the 1933 Chicago World's Fair and the coronation of Queen Elizabeth II. These books make previously unavailable material of regional and historic relevance accessible to researchers.

Currently under production, John Osborne's unique translation of Hans Jakob Christoffel von Grimmelshausen's Simplicissimus, the German Adventurer, won the University of Colorado's Kayden Award for the year's best literary translation of 1987. A new resource for scholars, this translation will also supplement the study of Western Civilization for undergraduates and will offer students of literature another work in the tradition of Don Quixote. The project illustrates the broadening of the ways librarians and faculty can collaborate to make scholarly materials accessible to students.

- Newfound Press values open access and increased visibility for scholarly information. David Lewis cites "a growing body of evidence that authors increase the impact of their articles" by making them "available through an open-access mechanism. ${ }^{" 12}$ Increased visibility benefits both authors and researchers. To explore issues involved in hosting an electronic journal and to gain experience with designing an interface, the press digitized three issues of the Journal of Economic Issues, a publication of the Association for Evolutionary Economics. The inaugural issue of Gamut, a born-digital publication of the Music Theory Society of the Mid-Atlantic, appeared in late 2007. For this project, the press migrated from its own interface design to open source software produced by PKP Open Journal Systems (OJS). ${ }^{13}$ This new software provides more functionality and makes the content more accessible; it also supports the inclusion of audio and video capability. Standardized metadata allows the work records to be harvested and indexed in search portals across the world, making the works more easily discoverable by potential researchers.

- Newfound Press values innovation and invites projects that employ digital multimedia to enrich the content. Researchers predict that "in the future, scholarship published online will be enhanced with embedded graphics, audio and video materials, all linked with datasets and applications needed to manipulate data." ${ }^{\text {14 }}$ Faculty already experimenting with new forms of publication may find a home for innovative projects with the press. A UT English professor has submitted a proposal for his compilation of manuscripts of Southern sermons written or delivered before 1800. This project holds the potential for enriching the content through multimedia, and the press hopes to attract more and varied multimedia submissions.

- Newfound Press values the broad dissemination of scholarly information beyond 
traditional books and journal articles. The experiment to provide selected conference proceedings demonstrates the benefit of adding media to text and enables wider distribution of the published proceedings. The Board recognizes that some disciplines value conference proceedings more highly than do other disciplines but sees value in making this often elusive and useful content available. Conference proceedings of The Road Home: [Cormac] McCarthy's Imaginative Return to the South, held at UT in the spring of 2007, include not only the text of the sessions but also video recordings, conference flyers, and news coverage. The libraries used collection funds to videotape the sessions, thereby preserving both the content and the dynamics of the event.

- The Newfound Press commitment to quality assumes that publications will undergo peer review. Editorial Board members have agreed to manage the review process for submissions in their general disciplinary areas. Clifford Lynch notes, "We are long overdue for a nuanced analysis and reevaluation of peer review practices in scholarly publishing." 15 The academy tends to reward faculty based on the reputation of the journal or press with which they publish. Newfound Press works to establish a respected reputation for publishing high-quality content useful to scholars and researchers. By prioritizing quality over marketability, the press hopes to provide a viable outlet for tenure-track faculty to publish works acceptable to promotion and tenure committees.

Creating and sustaining a press takes many kinds of expertise. Collection development staff maintain Web pages, employ new software, and generate layout. The outreach librarian contributes her expertise in book design. The Digital Library Center structures digital content, designs search features, and writes programming for access and use measurement. Metadata librarians apply standards that make the records universally harvestable by metadata aggregators. Two reference librarians help with editing and design and with promoting the press.
Sustainability requires a cost-effective means for publishing and providing access to scholarly information, including otherwise lost or hidden works. A small grant from the UT Office of Research helped fund software and Web page design for the Gamut project and provided money for student help. Other grant or endowment funds may provide further options. The Board still needs to determine the amount and source of sustainable funding, including the appropriate level of staffing, for the press to move forward.

For the future, Newfound Press envisions the project as more than a publishing venture. It will also sponsor programming to promote the discussion of relevant issues in the academy. The press partners with faculty to advance scholarly communication in the area of editing, as well as writing. Many faculty participate in the decisions scholarly societies make about the future of their specialized journals.

Newfound Press can provide information for making good decisions. The press encourages and nurtures younger faculty in their publication efforts, helping them learn the publishing culture and empowering them with information about trends in scholarly publishing. On a broader scale, the press looks forward to collaborating with other libraries that support digital publishing initiatives to create works that will convince promotion and tenure committees of their high quality.

The establishment of Newfound Press ${ }^{16}$ demonstrates that librarians can collaborate with faculty and other authors to explore new formats for publication. Working together, faculty and librarians can help shape this "pivotal moment for university-based publishing" 17 to expand the reach of scholarly communication.

\section{Notes}

1. See www.lib.utk.edu/newfoundpress/.

2. Cathy De Rosa, Lorcan Dempsey, and Alane Wilson, "The 2003 OCLC Environmental Scan: Pattern Recognition. A Report to the OCLC Membership," Ed., Alane Wilson. 
Dublin, OH: OCLC Online Computer Library Center, Inc., 2004: 62-63.

3. David W. Lewis, "A Strategy for Academic Libraries in the First Quarter of the 21st Century," College \& Research Libraries 68.5 (September 2007): 427.

4. Interview with Linda Phillips, head of collection development and management for the University of Tennessee Libraries, on September 28, 2007.

5. scholar.lib.vt.edu/ejournals/

6. parallelpress.library.wisc.edu/

7. For example, see: Shulenburger, David E. "On Scholarly Evaluation and Scholarly Communication: Increasing the Availability of Quality Work." College E Research Libraries News 62.8 (September 2001): 808-11.

8. For example, see: Clifford A. Lynch, "Improving Access to Research Results: Six Points." ARL No. 248. Washington, D. C.: Association of Research Libraries, 2006.

9. For example, see: Guédon, Jean-Claude. In Oldenburg's Long Shadow: Librarians, Re- search Scientists, Publishers, and the Control of Scientific Publishing. ARL Proceedings 138. Washington, D. C.: Association of Research Libraries, 2001.

10. Laura Brown, Rebecca Griffiths, and Matthew Rascoff, "University Publishing in a Digital Age," Ithaka Report, July 26, 2007 : 14.

11. Mark Sandler, "Collection Development in the Age Day of Google," Library Resources E Technical Services 50.4 (October 2006): 240.

12. Lewis, 425.

13. PKP Open Journal Systems, pkp.sfu. $\mathrm{ca} /$ ?q=ojs.

14. Brown, et al., 14.

15. Lynch, 7.

16. For further background on Newfound Press, see Linda L. Phillips, "Newfound Press: The Digital Imprint of the University of Tennessee Libraries," First Monday 12.10 (1 October 2007).

17. Brown, et al., 7. $\pi$

Ashgate Publishing, a leading independent publisher for 41 years, presents these new recommended library publications

\section{The Bronzes} of Rodin

Catalogue of Works in the Musée Rodin

Edited by Antoinette le Normand-Romain

"... a major contribution to the study of art history and a prime example of scholarly work executed with care, expertise, and devotion...Well ordered and accessible, with superb photographs, this represents a landmark in museum publishing and deserves a place in every art, academic, and large public collection."

—Paula Frosch,

Metropolitan Museum of Art Library, New York, LIBRARY JOURNAL

Distributed by Lund Humphries
in association with the Réunion des Musées Nationaux

2007. 800 pages in 2 volumes

978-2-7118-4939-0. Hbk. $\$ 300.00$

\section{Child Workers} in England, 1780-1820

Parish Apprentices and the Making of the Early Industrial Labour Force

Katrina Honeyman Studies in Labour History "This well-documented study is the first full account of pauper apprentices... Summing Up: Essential. Libraries supporting academic and research programs in history, upperdivision undergraduate and up."

—G.F. Steckley, Knox College, CHOICE, June 2008

2007. 354 pages

978-0-7546-6272-3. Hbk. $\$ 99.95$

2007. 268 pages 978-0-7546-7033-9. Hbk. $\$ 99.95$

Strategic Interests in the Middle East Opposition or Support for US Foreign Policy

Edited by Jack

Covarrubias and Tom Lansford

"... a timely look and useful for those interested in international relations, international security studies, and US foreign policy. Summing Up:

Recommended.

All undergraduate -S. Ayubi, Rutgers, The State University of New Jersey, CHOICE, June 2008 and graduate collections."

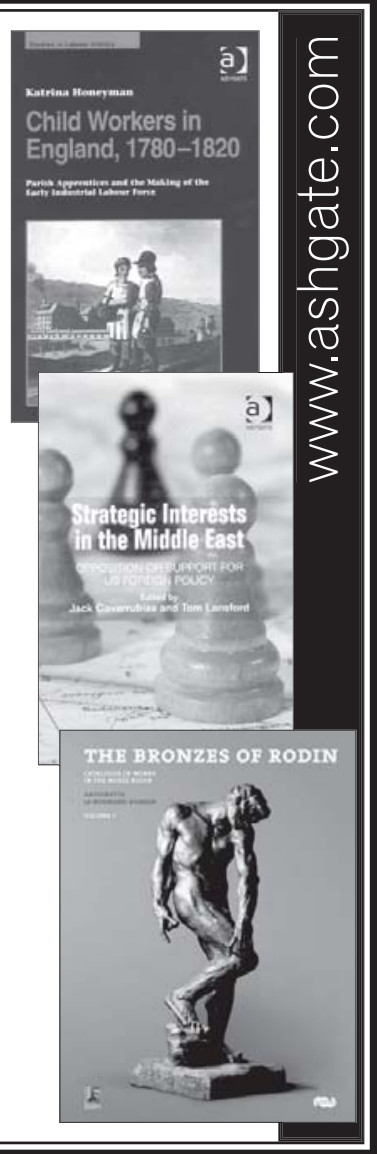

